\title{
Analysis of the Mechanisms of Development of the Russian Hydropower in the Post-Reform Period
}

\author{
V.V.Velikorossov ${ }^{1,}{ }^{*}$, E.V.Genkin ${ }^{1}$, A.K.Zakharov ${ }^{1}$, V.A.Kozlov ${ }^{1}$, A.K.Khudaibergenov ${ }^{2}$ \\ ${ }^{1}$ Department of Organizational and Administrative Innovations, Plekhanov Russian University of \\ Economics, Moscow, Russia \\ ${ }^{2}$ L.L.C. «Husnutdin Saliev», Nukus, Uzbekistan \\ *Corresponding author
}

Keywords: Hydropower, Renewable Energy, Strategic Management, Russian Economy, Aggregate Demand, Economic Growth

Abstract: The article discusses the prospects for the development of renewable energy sources in Russia, as well as the activities of one of the largest hydropower companies in the world - the Russian PJSC "RusHydro". The aim of the work is to analyze the mechanisms of development of Russian hydropower in the post-reform period.

\section{Methods of Research}

The survey included the following stages.

1. Macroeconomic analysis of the levels of electricity generation.

2. Analysis of reporting of energy companies.

3. Microeconomic analysis of Analysis of PJSC RusHydro business.

4. Analysis of volume of the world market of energy storage systems.

\section{Some Aspects of Macroeconomic Situation in Russia}

The current structure of macroeconomic policy ensures the stability of the Russian economy to changes in the external environment, including those associated with the possible introduction of new sanctions. In particular, due to macroeconomic structural reforms carried out in recent years, the sensitivity of the main macroeconomic indicators to the dynamics of oil prices and capital flows has significantly decreased compared to 2014.

Evidence of the increased stability of the Russian economy to external shocks is the dynamics of the ruble in recent months, characterized by increased volatility in the oil market. The price of Urals crude rose from a local low of $\$ 67.5$. US $\$$ per barrel on August 15, 2018, to a four-year peak of us \$ 84.5 per barrel. US per barrel recorded on October 4, 2018 (or $25.2 \%$ ). In the next month and a half, oil prices showed a comparable decline - by $26.8 \%$, to 61.8 dollars. US per barrel on November 21, 2018.

However, during this period, the ruble exchange rate against the us dollar remained stable (65.6 on November 21, 2018 compared with 66.8 on August 15, 2018), while its range of fluctuations was about 7 percent. For comparison, in the 4th quarter of 2014, with a comparable decline in oil prices, the ruble weakened by about a third in nominal terms relative to the us dollar. The observed 
dynamics indicates the increased confidence of Russian companies and households in the national currency. The situation in the banking sector has also remained stable in recent months.

Industrial production growth is supported by expansion of output of manufacturing industries (+3.2 percent $y / y$ in Jan-Oct). The key drivers of growth are food and chemical industries, wood processing. In addition, since the beginning of this year, a significant increase in production is observed in engineering.

However, growth has also accelerated in recent months in the mining complex. Mineral production for January-October 2018 increased by $3.3 \%$ yoy, while in September and October it showed the highest growth rates since 2014 (6.9\% yoy and $7.4 \%$ yoy, respectively). The continued acceleration in the extractive industry is primarily due to the increase in oil production as a result of the change in the parameters of the OPEC agreement in June 2018.

\section{Current Stage of Energy Development}

The world is entering a new stage of energy development, in which electricity, as the most convenient form of energy for consumers, will continue to displace other energy carriers.

In 2017, record levels of electricity generation were achieved. According to JSC "System operator of the Unified energy system of Russia" electricity consumption in Russia as a whole in January-June 2019 amounted to 541.0 billion $\mathrm{kWh}(-0.2 \%$ by 2018), production amounted to 551.3 billion $\mathrm{kWh}(+0.8 \%$ by 2018$)$. In the Far East (including isolated systems), electricity consumption in January-June 2019 amounted to 24.6 billion $\mathrm{kWh}(+1.3 \%$ by 2018$)$, production amounted to 26.2 billion $\mathrm{kWh}(+1.1 \%$ by 2018$)$.

At the same time, the industry will be characterized by two multidirectional trends. On the one hand, electricity demand will grow and the main growth in electricity consumption will be concentrated in developing countries in Asia, the middle East and Africa. On the other hand, the introduction of new technologies will ensure significant progress in energy efficiency, which will be demonstrated by all major countries and regions. However, the speed of this decline will depend on many socio-economic factors, as well as the conditions for the use of energy-saving technologies and the availability of investment resources to scale them.

And if the developed countries will be characterized by a rapid growth in the rate of solar, wind and gas generation to other types of hydrocarbon generation, the energy of developing countries will continue to be largely dependent on coal $[1,2,3]$.

In the short-term strategic perspective of 5-20 years in Russia is not expected a significant increase in energy consumption. Thus, in accordance with the forecast of demand for electric energy for the UES of Russia for the period 2018-2024, the average annual increase in electricity consumption for the UES of Russia for the forecast period will be 1.22 . In the longer term, consumption growth is also projected at this level.

\section{The Growing Role of Renewable Energy}

Technological changes do not bypass the electric power industry. Moreover, this applies not only to the development of technologies for generation, transmission and distribution of energy, as well as digitalization of the industry, but also the spread of new sources of consumption. There is every reason to expect a qualitative jump in the efficiency of electric power systems due to the introduction of new technologies, which will lead not only to a change in the way they are organized, but also to the transformation of market models.

However, the most important factor in increasing the competitiveness of renewable energy sources will be the development of economically attractive energy storage technologies, as well as the creation of favorable conditions for their implementation. In the future, progress in these 
technologies can radically increase the utilization rate of these capacities and make such generation competitive without any additional support [4].

High hydro potential of Russia is a prerequisite for consideration of energy storage, including in the form of hydrogen fuel, as well as its use as a tool for energy transportation. Energy storage systems open up fundamentally new opportunities for the development of the electric power industry and will significantly change the modern architecture of the electricity and capacity market by removing the mandatory condition in terms of the simultaneity of the processes of generation and consumption of electricity, as well as the active introduction of demand management technologies and price arbitrage [5].

In this regard, at present, many developed and developing countries are actively engaged in the formation of national markets for energy storage systems, considering the accumulation of energy as one of the key areas of energy development, and intensively developing the production of energy storage systems focused on the saturation of domestic and foreign markets. The main driver of growth in this case is technological progress, leading to a reduction in the cost of accumulation systems to an acceptable level for consumers, while improving their performance. The development of technologies will ensure the growth of the efficiency, reducing operating costs, as well as reducing the effect of increasing wear and tear of accumulating elements and maintaining their ability to accumulate and accumulate the necessary amount of electricity.

According to the forecasts of the Center for strategic development, the volume of the world market of energy storage systems in 2025 is estimated at 73.3 billion us dollars, McKinsey Global Institute has included this type of technology among the 12 most important for the development of world energy. In turn, Navigant Research predicts an increase in the annual input capacity of drives for RES from about $2 \mathrm{GW}$ in 2018 to $24 \mathrm{GW}$ in 2026 - 12 times in eight years, with a proportional increase in annual revenue to 24 billion us dollars by 2026 .

For Russia, taking into account the current situation in the industry, the development of electricity storage systems will significantly reduce the severity of problems associated with the classic "bottlenecks" of the system power industry, including both the UES and isolated zones and individual power units, as well as the formation and maintenance of electricity production and consumption $[6,7,8]$.

In addition, the active implementation of this direction and the formation of an appropriate competence center will contribute to the task of ensuring the technological independence of the energy sector and the development of sufficient competencies in all critical activities for sustainable energy development, with an increase in the level and expansion of the areas of global technological competitiveness of the Russian fuel and energy sector [9, 10, 11, 12, 15].

At present, the only well-developed technology of energy storage is hydro-accumulating power plants that convert electricity into potential energy of water supply, used at the right time, similar to conventional hydroelectric power plants. The growing need for energy storage systems has led to the development of scientific research and pilot projects that can dramatically increase the flexibility of decision-making and expand the scope of application.

\section{The Example of PJSC RusHydro}

PJSC RusHydro is the only organization in Russia that has successful experience in managing energy storage on an industrial scale (Zagorskaya PSP with a capacity of 1,200 MW and Zelenchuk HPP-PSP with a capacity of $300 \mathrm{MW}$ ).

The key results of RusHydro group's activities in 2016-2018 are presented in the following tables $[13,14]$. 
Table 1. Production Results of RusHydro Group in 2016-2018

\begin{tabular}{|l|l|l|l|l|l|}
\hline Indicator & 2016 year & 2017 year & Change, $\%$ & 2018 year & Change, \% \\
\hline Output, billion kWh & 138,8 & 140,3 & $+1,1 \%$ & 144,2 & $+2,8 \%$ \\
\hline including HPP TPP, & 109,4 & 109,7 & $+0,3 \%$ & 112,5 & $+2,6 \%$ \\
\hline $\begin{array}{l}\text { including } \\
\text { Geothermal }\end{array}$ & 30,6 & $+4,0 \%$ & 31,7 & $3,9 \%$ \\
\hline $\begin{array}{l}\text { Heat output, thousand } \\
\text { Gcal }\end{array}$ & 31,5 & 29,6 & $-5,0 \%$ & 29,7 & $-0,9 \%$ \\
\hline
\end{tabular}

Table 2. Financial Results of RusHydro Group in 2016-2018 according to RAS

\begin{tabular}{|l|l|l|l|l|l|}
\hline Indicator & 2016 year & 2017 year & Change, $\%$ & 2018 year & $\begin{array}{l}\text { Change, } \\
\%\end{array}$ \\
\hline Revenue, billion rubles & 391,3 & 380,9 & $-2,7 \%$ & 400,4 & $+5,1 \%$ \\
\hline EBITDA, billion rubles & 100,3 & 104,2 & $+3,8 \%$ & 109,7 & $+5,3 \%$ \\
\hline Profitability & $25,6 \%$ & $27,4 \%$ & & $27,4 \%$ & \\
\hline Net profit, billion rubles & 39,8 & 24,8 & $-37,7 \%{ }^{*}$ & 31,8 & $+28,5 \%$ \\
\hline
\end{tabular}

*The decrease in net profit is mainly due to the effect of recognition of impairment losses of fixed assets of the introduced facilities in the territory of the far Eastern Federal district (Yakut GRES-2).

Table 3. Financial Results of RusHydro group for 3 months 2019 under IFRS

\begin{tabular}{|c|c|c|c|}
\hline Name of indicator & 3 months of 2018 & 3 months of 2019 & Growth, $\%$ \\
\hline $\begin{array}{c}\text { Revenue, billion } \\
\text { rubles }\end{array}$ & 108,9 & 109,8 & $+0,8 \%$ \\
\hline $\begin{array}{c}\text { EBITDA, billion } \\
\text { rubles. }\end{array}$ & 31,7 & 29,6 & $-6,8 \%$ \\
\hline $\begin{array}{c}\text { Net profit, billion } \\
\text { rubles }\end{array}$ & 23,9 & 16,5 & $-31,0 \%$ \\
\hline
\end{tabular}

The economic efficiency of the PSP can also be improved by implementing the following measures:

- providing the PSP with the opportunity to submit market price applications, the price of which will take into account the cost of electricity purchased on the market when working in the pumping mode;

- consolidation in the regulatory legal framework of the provision on the absence of the PSP need to pay for power consumption and services for the transmission of electric energy when working in the pumping mode; 
- the introduction of new paid system services for regulation of the power system due to malomanevrenny generation facilities for capacity maneuver;

- establishment of tax preferences in terms of reducing/zeroing the rate of property tax, water tax and income tax [11].

The integral effect for the economy of the country in the implementation of these measures includes: improving the reliability of energy supply and power regulation in the power system, the possibility of building nuclear power plants next to the regulatory PSPP, limited in the possibilities of regulating power in the power system, but are at the same time a cheap source of electricity, income from job creation, tax and social payments, the creation of related infrastructure during construction, the effect of reducing the tariff for the end user, additional investments in the economy of the regions (saving, received by the generator taking into account the specified support measure).

\section{Conclusions}

The survey concludes that there is a significant hydro potential of Russia, as well as significant accumulated experience in the design, construction and operation of the power plant is due, including construction of major and medium hydropower stations. A positive trend in the activities of PJSC RusHydro in recent years has been noted. In 2016 and 2017, RusHydro paid a record dividend in the history of the company, amounting to 15 billion rubles (almost 4 kopecks per share) at the end of 2015 and 19.9 billion rubles (4.7 kopecks per share) at the end of 2016 (more than $60 \%$ of dividends go to the budget of the Russian Federation). In 2018, the company paid 11.2 billion rubles (2.6 kopecks per share). PJSC RusHydro plans to continue paying dividends at the level of $50 \%$ of net profit. RusHydro group has achieved a high level of financial stability. For the first time in the company's history, the international credit ratings of RusHydro Group have been raised to the sovereign level of the Russian Federation (S\&P BBB -, Moody's Va1, Fitch BBB -). ACRA has been assigned a credit rating on the national scale at the highest level of reliability "AAA(ru)". RusHydro valued enough compared with the Russian generating companies. It is revealed that in its activities the management of PJSC "RusHydro" also uses a risk-based approach to management decisions taking into account the risks of production, financial and regulatory nature, including those affecting the value of the company. It is concluded that the most important factor in improving the competitiveness of renewable energy sources will be the development of economically attractive energy storage technologies, as well as the fact that currently the only welldeveloped technology of energy storage are hydroelectric power plants.

The mechanisms of Russian hydropower development considered in the article can be used to improve the strategies of energy companies both in Russia and in the world.

\section{References}

[1] Ekspertno-analiticheskij doklad «Cifrovoj perekhod v elektroenergetike Rossii». CSR. 2017.

[2] Velikorossov V.V., Genkin V.E., Zaharov A.K. Innovacionnye strategicheskie podhody k strukturnoj modernizacii energetiki v Rossii // Ekonomika i upravlenie: problemy, resheniya (nauchno-prakticheskij zhurnal). - 2019. - №3, tom 5 (87). S .112-121.

[3] Technology Roadmap. Energy storage. The International Energy Agency (IEA). 2014.

[4] World Energy Outlook. IEA, 2008 - 2017.

[5] Zaharov A.K. Innovacionnaya koncepciya ustojchivogo razvitiya rossijskoj energetiki. -M.: Energoatomizdat, 2004. - 176 s. -ISBN 5-283-01284-0. 
[6] Disruptive technologies: Advances that will transform life, business, and the global economy. McKinsey Global Institute. 2013. 176 p.

[7] Electricity storage and renewables: costs and markets to 2030. The International Renewable Energy Agency (IRENA). 2017.

[8] Velikorossov V.V., Zaharov A.K., Kozlov V.A., Sulimova E.A. Perspektivy razvitiya gidroenergetiki Rossijskoj Federacii v sovremennyh ekonomicheskih usloviyah (na primere PAO «RusGidro») / Global'nye energeticheskie i ekonomicheskie trendy/ Pod redakciej d.e.n. S.V. ZHukova, M., IMEMO RAN, 2019, S.139-153.

[9] Proekt Energeticheskoj strategii Rossii do 2035 goda.

[10] Kozlov V.V., Zaharov A.K. Innovacionnoe razvitie elektroenergetiki Rossii i ee rol' v obespechenii energeticheskoj bezopasnosti strany (na primere razvitiya atomnoj energetiki) / Innovacii i investicii. 2015. №1 S.2-6

[11] Prognoz dolgosrochnogo social'no-ekonomicheskogo razvitiya Rossijskoj Federacii na period do 2036 goda (utverzhden na zasedanii Pravitel'stva Rossijskoj Federacii 22.11.2018).

[12] Khachaturyan M.V., Klicheva E.V., Velikorossov V. V. (2019) Digital Mechanisms of Development of Possessory Risk Management Systems under New Economic Conditions. Proceedings of the 2019 International Conference on Politics, Economics and Management (ICPEM 2019). Lecture Notes in Economics, Management, and Social Sciences. Clausius Scientific Press, Vol. 5. P. 6-10.

[13] Godovye otchety PAO «RusGidro» za 2016-2018 god.

[14] Internet-sajt PAO «RusGidro»: URL: www.rushydro.ru

[15] Goncharenko L.P., Sybachin S. A., Khachaturyan M. V. Peculiarities of Organizational Economic Mechanism Development in correspondence with State Strategic Management in Russia. Proceedings of Conference Trends of Technologies and Innovations in Economic and Social Studies (TTIESS 2017). Advances in Economics, Business and Management Research, volume 38, 2017. Atlantis Press, 2017 